\title{
I: 30 Contemporary Popular Culture
}

\section{Definition}

After being a character in the Marvel comics franchise, Pórr (Thor) has now become a movie star. Elves, dwarfs and trolls are playable characters in online role playing games. Óðinn (Odin) walks among humans in the best-selling novel, American Gods, and Ragnarr Loðbrók is the main character of an Irish-Canadian drama television series. As we can see, references to medieval Scandinavian stories are wide-spread nowadays in the cultural industry productions often called 'popular culture'. One must be careful, however, when using this expression, which has various definitions (Storey 2008, 1-12) and implies answers to multiple questions regarding memory, which can be defined as the contemporary presence of representations of the past (Ricoeur 2000, 5). As Peter Burke (2008 [2004], 27) states, popular culture is often used as a 'residual category' which serves to designate the culture of the non-elite. Other terms have been proposed, such as sub-culture, alternative culture, counter-culture, but, when using notions of this kind, "we run the danger of assuming the homogeneity of the excluded" (Burke 2008 [2004], 27). Thus, they should not be used as strict delineating categories; rather, researchers should attempt to understand the formation of these categories and the relations between them.

The term popular culture is often opposed to a higher standard of culture, sometimes called elite culture or learned culture, leading to a hierarchical vision where productions designated as popular are considered inferior. That is why productions designated as popular culture in the sense of a 'residual category' are not usually considered as official sets of resources for institutional memory, like national memory. They do not offer official testimony of the past. On the contrary, popular culture is linked to mass production and "commercialisation of culture and leisure" (Strinati 2004 [1995], 1). The term refers to the processes of reproduction and diffusion of media products as "consequences of industrialisation and urbanisation" (Strinati 2004, 5). Such phenomena participate in the process of globalisation (Appadurai 1996) and refer to cultural identity and community constructions. In this sense, it can be used to understand how the diffusion of cultural products serves to spread and share cultural references through the notion of 'collective memory' suggested by Maurice Halbwachs (1950). But despite this collective aspect, researchers should not assume the homogeneity of memory. On the contrary, differences are as important as similarities in understanding the conflicts emerging from attempts to build a collective memory. Memory may be 
linked to a group (Ricoeur 2000, 146-151), but popular culture does not have a fixed set of productions and even less common practices among social actors.

Stuart Hall argues that the term popular is often associated with the manipulation and devaluation of the majority of people by the minority who control the media. He discusses this notion and insists that people, especially the labouring or working class, should not be taken for 'cultural dopes'. Instead, researchers should consider the resistance that these people show to media determinism. He points out the power struggles and processes of legitimation by highlighting the dialectic between "containment" and "resistance" (Hall 1998 [1981], 443). In other words, Hall deals with the question of how signification is constructed: is it imposed by an objective order or is it the result of subjective and personal appropriations and transformations? This question is transposable with memory studies, as it leads to an examination of power relations and the construction of legitimacy in memorial activities. The meaning of memory in popular culture products must therefore be understood as a conversation between the activities of the producers and the various appropriations of the consumers. In other words, there is a subjective part in the construction of memory that must be taken into account.

In a similar way, for Michel de Certeau (1990 [1980]), popular culture is the culture of ordinary people that is constituted and renewed through everyday activities. He defines consumption as an appropriation, that is an active process through which people take over merchandised products. With his idea of 'arts of doing', Certeau's reflections address the question of the production of everyday life culture. Memory can be understood as the construction processes of a relationship between the past and the present in which the former serves the latter (Baussant 2007, 389). This notion intersects with popular culture in research questions about understanding how cultural elements are used and always renewed in everyday life to build and maintain links between the past and the present.

\section{State of research}

Peter Burke (2008 [2004], 67) remarked that "there is a strong popular interest in historical memory". Jerome de Groot (2009) has shown several ways in which contemporary popular culture offers to consume history and heritage, and interdisciplinary research crossing religious studies with cultural studies is still a young field (Clark 2012, 1). Nevertheless, in Scandinavian studies, some attention has already been given to popular productions, even if they do not always directly address the question of memory. 
Much research focuses on content analysis, influences and transformations. The appropriation and international diffusion of Thor within the Marvel franchise, an American comics company, is a good example of the history of reception of Norse elements worldwide (Arnold 2011). Several examples can also be taken from fantasy literature. The major example is, of course, J. R. R. Tolkien's writings, which borrow much of their content from various traditions, especially Norse medieval literature (Simek 2005). But other fantasy authors also borrowed from such sources, such as Georges R. R. Martin's novels A Song of Ice and Fire, which gained popularity thanks to their adaptation as a TV show, Game of Thrones (see Larrington 2016). As one can see, many productions that are part of the so-called popular culture do not deal with memorial issues but make use of Norse elements in new contexts and build an image of Norse traditions as a set of resources from which one can freely draw. As a consequence, most of the academic work addressing popular culture does not integrate the question of memory and tradition and mostly deals with literary influences, receptions and adaptations.

The Texan author, Robert E. Howard, often considered one of the founding fathers of fantasy literature, especially the American sub-genre Sword and Sorcery, must also be taken into account (Parsons 2015). He is the creator of numerous characters including Conan, the famous barbarian. The setting of Conan's stories, the Hyborian Age, is a pre-cataclysmic version of our own world, during which the events that occur gave birth to the myth and legends that we know. In other words, in his fictional world, Howard develops a euhemeristic vision (Di Filippo 2016, 170-179). Deeper interdisciplinarity and crossed methodological approaches allow for the interpretation of his work, from a sociological point of view, as the result of social activities taking place in the 'art worlds' (Becker 1982) of literature, as well as the diffusion taking place within an evolving franchise and transmedia context, and the variety of appropriations by consumers (Di Filippo 2016). Understanding the transmission processes as contributing to the construction of memory is thus not limited to only a few disciplines, and especially not just to history. The inclusion of several research fields gives a more precise understanding of memorial processes.

Peter Burke (2008 [2004], 67) explains the popular interest in memory as a probable "reaction to the acceleration of social and cultural change that threatens identities by dividing what we are from what we were". Some research objects make clear references to Norse cultural elements within identity construction processes, as in the case of music, especially in Metal and its sub-genres, Pagan Metal and Viking Metal, which use romantic representations of the North and binary oppositions between pagan religions and Christianity (Bénard 2004, 2009; Heesch 2010). This kind of dualism also appears in recent neo-pagan reconstruction religious movements, which have roots in nineteenth-century Romanticism 
(François 2007; von Schnurbein 2016) and can now be found even on Brazilian internet websites (Antunes and Pires Boulhosa 2011). In such cases, the discourse itself can be impregnated with the social actors' need to construct a collective memory for themselves and/or their audience, and this discourse must therefore be contextualised in order to understand the external constraints on it (Baussant 2007) and their adaptation and transformation during specific social situations and interactions. For example, Anders Breivik used references to Norse myths from the music of the video game Age of Conan in his manifesto to promote the fight against Islam and multiculturalism (Di Filippo 2016, 355). This use is not an expression of the video game itself. It must be understood in relation to farright political opinions that Breivik developed in contact with other political discourses.

As the variety of examples shows, references to medieval Scandinavian narratives may take many forms. Research must take this diversity into account as it questions the homogeneity of so-called popular and collective memory. Going a step further, one should consider how memory is used to promote a sense of belonging in a group, both in space and time, and what mechanisms are used by social actors to reach this goal, in order to understand the ideology that drives them.

\section{Pre-modern Nordic material}

References to Old Norse stories are used in various ways, sometimes to depict a Norse setting, such as in the TV series Vikings. In cases like these, memory studies should focus on how the representations, the mise en scène, and the discourses surrounding cultural productions, influence the collective representations of the past. At other times, Norse components stand among numerous references to various ancient traditions. This is the case in many role playing games, from Dungeons and dragons (TSR 1974) to massive multi-player online role playing games like World of Warcraft (Blizzard 2004). Some components are used to depict the Northern regions of fantastic worlds, as in Age of Conan: Hyborian Adventures (Funcom 2008), and others elements, such as runes and berserkers, are now so wildely spread that their origin in Old Norse language and texts is no longer relevant. For example, the series of Japanese role playing games Suikoden (Konami 1995) are centred around the story of the 'true runes' and their bearers. The term berserker can also be used to qualify Asian-type warriors and even animals (Di Filippo 2016, 255-257). They are now part of a wider 'geek aesthetic'. Through the mediation of literature, and especially the fantasy genre inspired by 
J. R. R. Tolkien, creatures such as elves, dwarfs, trolls, and giants can be found in numerous productions, even in futuristic cyberpunk worlds like games and novels of the Shadowrun franchise (FASA 1989). One can even find references to Norse traditions in movies like Mad Max: Fury Road. Its 'war boys' are a group of men fighting for the dictator "Immortan Joe". Their dream is to die fighting and go to Valhalla, where they will be "Mcfeasting" with other 'immorta'. This is a reference to both Old Norse mythology and the fast food brand McDonald. This post-apocalyptic setting shows how the destruction of the world led to a blending of traditions. At the same time, it offers social critique by showing that modern fast food is so widespread that it takes the form of a modern myth, in the sense of Roland Barthes, which could be mistaken for ancient literary traditions. Such blending leaves trails through which one can study cultural hybridity (Burke 2009) and how Norse elements mix more or less easily with other traditions. It also serves to underscore the fact that memory is the result of transformations which took place throughout time.

The majority of these borrowings stand as un-contextualised elements. As many researchers have pointed out, memory goes along with forgetting (Anderson 1991 [1983], 204; Todorov 2004 [1995], 14; Augé 2001 [1998]; Ricoeur 2000, 536). Researchers should therefore take into account both processes in their study to understand what part of culture is transmitted and what part is forgotten or left aside. In the previously mentioned examples, many references are used without specifying their sources or their original contexts, a fact that leads to a loss of knowledge about the status of elements that are borrowed.

\section{Perspective for future research}

Several perspectives are opened by the numerous ways in which contemporary popular culture productions make references to Old Norse traditions and literature. First of all, the increasing variety of references to Old Norse should encourage Scandinavian scholars to study how elements from the literate class in medieval Scandinavia became part of widespread cultural productions, which are reproduced in industrial quantities and shape a growing part of modern leisure activities and create interest in the North among people of all ages. Cultural dynamics of this sort illustrate the changes and variations of culture and class through time. In terms of memory studies, such reception stresses the fact that the same documents and resources are used as memorial references by various groups throughout history. The conditions of memorial dynamics (Baussant 2007) evolve 
as different people are put in contact with traditional cultural elements and sources.

Another entry point already proposed by Terry Ray Clark $(2012,1)$ suggests that the study of ideology still needs to be developed for products beyond neopagan practices or music. But, in order to avoid so-called media-determinism, social actors should not be taken as cultural dopes. Individuals are able to recognise fiction and games as such, and keep a certain distance when consuming representations as commercial goods (for detailed references on such topics see Di Filippo 2016, 277-282 and 470-473). Using sociological and ethnographical methods, such as interviews, observation and even participant observation, it is possible to avoid oversimplified interpretations based on content analysis alone, especially when studying contemporary practices. Such methods will allow the study of situated uses of memorial phenomena.

None of those practices stand alone, but they are related to many other activities. That is why researchers in the field of Scandinavian studies ought to study more deeply how modern knowledge of Old Norse tales, traditions, history and myths is constructed for the general public. Many dictionaries and encyclopaedias, as well as online sources such as Wikipedia, offer simplified information. For example, despite the fact that the modern use of 'myth' was fashioned during the nineteenth century (built on Greek and Latin etymons) and no such word existed in Old Norse, the term is still widely used to describe medieval narratives, even among specialists, and gives a false idea of the function of those texts and their sources (Di Filippo 2016, ch. 1). In this case, the study of linguistic categories and their evolution will help to understand how people express and categorise their ideas about memory and how the past is represented.

Finally, Scandinavian scholars should themselves take an active part in memory processes as cultural 'passeurs [conveyors/transmitters]', as there are no strict lines between learned and popular culture but instead, they nourish each other over time.

\section{Works cited}

\section{Secondary sources}

Anderson, Benedict. 1991 [1983]. Imagined Communities: Reflections on the Origin and Spread of Nationalism. London.

Antunes, Gabriela and Patricia Pires Boulhosa. 2011. "Neo-paganism and Nordic Mythology on the Brazilian Internet." In Eddische Götter und Helden. Milieus und Medien ihrer Rezeption. Eddic Gods and Heroes. The Milieux and Media of their Reception. Ed. Katja Schulz. Heidelberg. 367-380. 
Appadurai, Arjun. 1996. Modernity At Large: Cultural Dimensions of Globalization. Minneapolis. Arnold, Martin. 2011. Thor. Myth to Marvel. London and New York.

Augé, Marc. 2001 [1998]. Les formes de l'oubli. Paris.

Becker, Howard Saul. 1982. Art Worlds. Berkeley, CA.

Bénard, Nicolas. 2004. "De la légende Viking au Hard-Rock: les références culturelles du Métal Nordique.” Nordiques 5: 55-68.

Bénard, Nicolas. 2009. "Les mythologies Hard Rock et Métal: Bricolage identitaires ou récit original?” Sociétés 104: 65-72.

Baussant, Michèle. 2007. "Penser les mémoires.” Ethnologie française, XXXVII.3: 389-394.

Burke, Peter. 2008 [2004]. What is Cultural History? Cambridge and Malden, MA.

Burke, Peter. 2009. Cultural Hybridity. Cambridge and Malden.

de Certeau, Michel. 1980 [1990]. L'invention du quotidien. 1. Arts de faire. Paris.

Clark, Terry Ray. 2012. "Introduction: What is Religion? What is Popular Culture? How are they Related?" In Understanding Religion and Popular Culture. Theories, Themes, Products and Practices. London and New York. 1-12.

Di Filippo, Laurent. 2016. Du mythe au jeu. Approche anthropo-communicationnelle du Nord. Des récits médiévaux scandinaves au MMORPG Age of Conan: Hyborian Adventures. PhD Thesis in communication studies and scandinavian studies: University of Lorraine/ University of Basel.

François, Stéphane. 2007. Le Néo-paganisme. Une vision du monde en plein essor. Apremont. de Groot, Jerome. 2009. Consuming History. Historians and Heritage in Contemporary Popular Culture. Oxford and New York.

Halbwachs, Maurice. 1950. La mémoire collective. Paris.

Hall, Stuart. 1998 [1981]. "Notes on deconstructing the popular". In Cultural Theory and Popular Culture. A Reader. Ed John Storey. Harlow. 442-453.

Heesch, Florian. 2010. “Metal for Nordic Men: Amon Amarth's Representations of Vikings.” In The Metal Void. First Gatherings. Ed. Niall W. R. Scott. Oxford. 71-80.

Larrington, Carolyne. 2016. Winter is Coming. The Medieval World of Game of Thrones. London and New York.

Parsons, Deke. 2015. J.R.R. Tolkien, Robert E. Howard and the Birth of Modern Fantasy. Jefferson, NC.

Ricoeur, Paul. 2000. La mémoire, l'histoire, l'oubli. Paris.

von Schnurbein, Stefanie. 2016. Norse Revival. Transformations of Germanic Neopaganism, Leiden and Boston, MA.

Simek, Rudolf. 2005. Mittelerde. Tolkien und die germanische Mythologie. Munich.

Storey, John. 2008. Cultural Theory and Popular Culture. An Introduction. $5^{\text {th }}$ ed. Harlow.

Strinati, Dominic. 2004 [1995]. An Introduction to Theories of Popular Culture. London and New York.

Todorov, Tzvetan. 2004 [1995]. Les abus de la mémoire. Paris. 